\title{
Combining ability and genetic parameters of some white maize (Zea mays L.) inbred lines using diallel analysis
}

\author{
Hemada S. SH. ${ }^{a}$ Yassien H. E. ${ }^{b}$, Abd El-Zaher I. N. ${ }^{a}$, Haridy M. H. ${ }^{a^{*}}$ \\ ${ }^{a}$ Department of Agronomy, Faculty of Agriculture, Al-Azhar University, Assiut, Egypt \\ ${ }^{b}$ Department of Agronomy, Faculty of Agriculture, Al-Azhar University, Cairo, Egypt
}

\begin{abstract}
Nine inbred lines $\left(\mathrm{S}_{5}\right)$ of white maize derived from Giza -2 and IW- 469 were crossed using of half diallel cross mating design, during spring season of 2019 at the Farm of Faculty of Agriculture, Al-Azhar University at Assiut Branch, to produce thirty six $\mathrm{F}_{1}$ crosses. The parents, crosses and tow checks i.e. SC-163 and SC-10 were evaluated during spring season of 2020 in R.C.B.D with three replications to determine combining ability, heterotic and gene action effects. Significant differences were found among parental and their crosses as well as for general combining ability (GCA) and specific combing ability (SCA) for all studied traits. The previous results indicating the importance of both additive and non-additive genetic effects for studied traits. The ratio of $\Sigma \mathrm{g}^{2} \mathrm{i} / \Sigma \mathrm{S}^{2} \mathrm{ij}$ was less one for all studied traits, indicate that the non-additive gene action in the inheritance of all the studied traits. Parents P1 and P4 showed best GCA effects for grain yield/plant, while the parents P2 and P6 appeared to be the best general combiners for most of the studied traits. The crosses P1 $x$ P8, P2 $\times$ P6 and P2 $\times$ P5 appeared to be the best mean performance, SCA and superiority percentage for most studied traits. The values of the broad sense heritability were high $(>80 \%)$ for all studied traits. While, the narrow sense heritability was low for grain yield/plant (13.00\%). Results indicated that some inbred lines could be used in breeding program to develop single crosses which have higher grain yield.
\end{abstract}

Keywords: maize, half diallel cross, combining ability, heterosis, genetic parameters.

*Corresponding author: Hemada S. SH., 


\section{Introduction}

Maize (Zea mays L.) is an important cereal crop and it ranks as the third position after wheat and rice. Maize plays a significant role in human and livestock nutrition world-wide. Moreover, it confirms the basis of several industries such as; starch, cooking oil and main of animal food. There is a critical need to increase the production of maize to face the gap between production and consumption. The concepts of general (GCA) and specific (SCA) combining abilities are useful for charactering inbred lines in their crosses as defined by Sprague and Tatum (1942) .Exploitation of hybrid vigor and selection of parents based on combining ability has been used as an important breeding approach in crop improvement (Uddin et al., 2006). Developing of high yielding F1's along with other favorable traits is receiving considerable attention. El-Beially et al. (2007) reported that the variance component due to lines and crosses was highly significant for yield and its components. For developing desirable hybrids, information about combining ability of the parents and the resulting crosses is essential. The variances of general and specific combining ability are related to the type of gene action effects. Variance for GCA includes additive portion while that of SCA includes nonadditive portion of total variance arising largely from dominance and epistatic deviations (Rojas and Sprague, 1952). Diallel cross have been widely used in genetic research to investigate the inheritance of important traits among a set of genotypes. These were devised, specifically, to investigate the combining ability of the parental lines for the purpose of identification of superior parents for use in hybrid development programs. Information about inheritance pattern of any specific trait can be obtained from Griffing (1956) provides a feature on genetic action of parental lines. Dudley and Moll (1969) defined heritability as the ratio for genetic variance to phenotypic variance. Also heritability was defined by Lush as the proportion of phenotypic variance among individuals in a population that is due to heritable genetic effects, this definition is now termed as heritability in narrow sense and it is designated ( $\mathrm{H}$ or h2n.s). The aims of the present investigation were to estimate GCA and SCA combining ability effects of the nine inbred lines and its combinations to identify the best combiners and crosses to improve maize for earliness traits, yield and its components. Also, to determine the important types of gene action effects that controls the studied traits.

\section{Materials and methods}

\subsection{Plant materials and field experiments}

Nine inbred lines $\left(\mathrm{S}_{5}\right)$ of white maize viz. P1, P2, P3, P4, and P5 it was derived from it Giza-2 population, while, P6, P7, P8 and P9 derived through selection from the population of IW-469 These lines were crossed according to a half diallel crosses mating design during summer season of 2019 in Farm of Faculty of Agriculture, Al-Azhar University (Assiut 
Branch), Egypt. During summer season 2020, the $36 \mathrm{~F} 1 \mathrm{~s}$, nine parental lines, and tow checks i.e., SC-10 and SC-136 were grown in a Randomized Complete Block Design with three replications. Each plot area was $6.3 \mathrm{~m} 2$, which consisted of 3 ridges, each of $3 \mathrm{~m}$ long and $70 \mathrm{~cm}$ apart. The distance between hills was $25 \mathrm{~cm}$. The agricultural practices of irrigation, fertilization, weeds and pest control were used as normal recommended for maize production. Samples of ten guarded plants were taken at random from middle ridge of each plot to determine the following traits i.e. days to $50 \%$ tasseling (day), as number of days from planting until $50 \%$ of the plants showed their tassels , days to $50 \%$ silking (day), as number of days from planting until 50\% of the plants showed their silks, plant height $(\mathrm{cm})$, height from the ground surface to the base of the tassel, ear height $(\mathrm{cm})$ height from the ground surface to the top-most bearing node, ear length in $(\mathrm{cm})$, ear diameter in $(\mathrm{cm})$, 100-kernel weight and grain yield/plant in grams, adjusted to $15.5 \%$ moisture content.

\subsection{Statistical analysis}

Data collected from genotypes were subjected to an ordinary analysis of variance of RCBD to test the significance of differences among the genotypes. Bartlett test as described by Steel and Torrie (1980) was used to test the homogeneity of error variance and treatments means were compared statistically using the test of the Lest Significant Differences (L.S.D). The combining ability effects and types of gene action were estimated according to Griffing's (1956), diallel cross analysis, Method 2, Model 1.

\subsection{Superiority percentages}

Superiority percentages were determined for individual crosses as the percentage deviation of $F_{1}$ means from over check, and was calculated as follow:

Standard heterosis $=\frac{\mathrm{F} 1-\text { check variety }}{\mathrm{F} 1} \mathrm{X} 100$

Standard heterosis (L.S.D) $=\mathrm{t} \cdot \sqrt{2} M S e / r$

Where, $\mathrm{t}$ is the tabular value at the stated level of probability for the degrees of freedom of the experimental error.

\subsection{Estimation of variance components}

The genetic analysis was based on Griffing's (1956) method 2 - fixed model 1 determine the variance and effects of general and specific combining ability, additive, dominance and environmental variance, average degree of dominance. Heritability in broad and narrow sense was determined. Expected genetic advance in absolute and percentage was calculated.

\subsubsection{General and specific combining ability}

The variance of the general and specific combining ability was calculated according to Singh and Chaudhary 
(1979).

$\sigma^{2} \mathrm{gca}=\left(\mathrm{MS}_{\mathrm{gca}}-M e ́\right) /(\mathrm{P}+2)$

$\sigma^{2} \mathrm{sca}=\left(\mathrm{MS}_{\mathrm{sca}}-M e ́\right)$

$\sigma^{2} \mathrm{~A}=2 \sigma^{2}$ gca, $\sigma^{2} \mathrm{D}=\sigma^{2} \mathrm{sca}$

$\sigma^{2} \mathrm{E}=M e ́=\mathrm{Mse} / \mathrm{r}$

$\sigma^{2} \mathrm{G}=\sigma^{2} \mathrm{~A}+\sigma^{2} \mathrm{D}=2 \sigma^{2} \mathrm{gca}+\sigma^{2} \mathrm{sca}$

$\sigma^{2} \mathrm{P}=\sigma^{2} \mathrm{G}+\sigma^{2} \mathrm{E}$

\subsubsection{The average degree of dominance}

If: $\overline{\mathrm{a}}=$ zero denotes no dominance; $\overline{\mathrm{a}}<1$ denotes partial dominance; $\overline{\mathrm{a}}=1$ denotes complete dominance, and $\overline{\mathrm{a}}>1$ denotes over dominance (Comstock and Robinson, 1952).

$\mathrm{a}^{-}=\frac{\sqrt{2 \sigma 2 \mathrm{D}}}{\sigma 2 \mathrm{~A}}$

Where: $\sigma^{2} \mathrm{~A}=$ additive genetic variances, $\sigma^{2} \mathrm{D}=$ dominance genetic variances, $\sigma^{2} \mathrm{P}$ $=$ phenotypic variances, $\sigma^{2} \mathrm{E}=$ environmental variances, $\sigma^{2} \mathrm{G}=$ genotypic variances.

\subsubsection{Heritability}

Heritability further divided into broad sense and narrow sense, broad sense heritability was estimated as the ratio of genotypic variance to the phenotypic variance and was expressed in percentage, and narrow sense heritability was calculated by dividing additive variance by total variance.

Heritability in broad sense

$h^{2} b . s=\sigma^{2} G / \sigma^{2} P$

Heritability in narrow sense $h^{2} \mathrm{n} . s=\sigma^{2} \mathrm{~A} / \sigma^{2} \mathrm{P}$

Heritability values in broad sense less than $40 \%$ were considered low, 40 to $60 \%$, medium and more than $60 \%$ were considered high (Ali, 1999) and AlFarari (1999) reported that, heritability in narrow sense is considered low if it was less than $20 \%, 20$ to $50 \%$ as medium and high if it is more than $50 \%$.

\subsubsection{Genetic advance}

Genetic advance was calculated according to the following formula:

$\mathrm{G}=\mathrm{h}^{2}$ n.s. i. $\mathrm{p}$

$\mathrm{h}^{2} \mathrm{n} . \mathrm{s}=$ heritability in narrow sense; $\mathrm{i}=$ selection intensity $10 \%=1.76$ and $\sigma p=$ phenotype standard deviation. After that, the excepted genetic advance as present was calculated according to the following equation:

$\% \Delta \mathrm{G}=(\Delta \mathrm{G} / \mathrm{y} ..){ }^{*} 100$

Where; $\Delta \mathrm{G}=$ Genetic advance, $\mathrm{y} . .=$ mean of population. The value of genetic advance is considered high when it is more than $30 \%$, medium when the result is between 10 to $30 \%$ and is considered low when it is less than 10\%, (Ahmed and Agrawal, 1982).

\section{Results and Discussion}

\subsection{Analysis of variance and mean performance}

The analysis of variance revealed that the mean squares due to genotypes, parents, crosses and parents v/s crosses were 
significant or highly significant for all the studied traits (Table 1). Significant mean squares due to parents and crosses suggested that the parental lines selected were diverse and with a different genetic background. Similarly, significant mean squares due to parents v/s. crosses indicated presence of considerable amount of variability and overall heterosis for all the traits under study. These results were in confirmation with El-Beially (2003), El-Beially et al. (2007), Sundarajan and Kumar (2011), Avinashe et al. (2013), Al-Hadad et al. (2015), Darwish et al. (2016), Sadalla et al. (2017), Mostafa (2018) and Rohman et al. (2019). Moreover, Analysis of variance for combining ability (Table 1), revealed that both general (GCA) and specific (SCA) combining ability mean squares were highly significant for all studied traits, these results indicating that the importance of additive as well as non-additive type of gene action in the inheritance of all the studied traits. The magnitude of GCA was more than that of SCA for all studied traits, except grain yield / plant. These results indicated that the additive genes are responsible for most of the genetic variation for those traits. In contrast, the ratio of $\Sigma \mathrm{gi}^{2} / \Sigma$ $\mathrm{Sij}^{2}$ was less one for all studied traits indicating the non-additive gene action plays an important role in the inheritance of all the studied traits. Therefore, selection procedure in late or advanced generations will be very important to improve these traits.

Table (1): Mean squares of analysis of variance and combining ability for studied traits.

\begin{tabular}{|c|c|c|c|c|c|c|c|c|c|}
\hline S.O.V & d.F & $\begin{array}{l}\text { Number of days } \\
\text { to } 50 \% \text { tasseling }\end{array}$ & $\begin{array}{l}\text { Number of days } \\
\text { to } 50 \% \text { silking }\end{array}$ & $\begin{array}{l}\text { Plant height } \\
(\mathrm{cm})\end{array}$ & $\begin{array}{l}\text { Ear height } \\
\text { (cm) }\end{array}$ & $\begin{array}{l}\text { Ear length } \\
(\mathrm{cm})\end{array}$ & $\begin{array}{l}\text { Ear diameter } \\
(\mathrm{cm})\end{array}$ & $\begin{array}{l}\text { 100- kernel } \\
\text { weight }(\mathrm{g})\end{array}$ & $\begin{array}{c}\text { Grain } \\
\text { yield/plant (g) }\end{array}$ \\
\hline Genotypes & 44 & $60.69 * *$ & $50.51 * *$ & $1649.38 * *$ & $661.46 * *$ & $10.08 * *$ & $0.45^{* * *}$ & $19.09^{* * *}$ & $11097.86^{* * *}$ \\
\hline Crosses & 35 & $49.20^{* *}$ & $41.47 * *$ & $1101.56^{* * *}$ & $490.85^{* *}$ & $4.70 * *$ & $0.25^{* * *}$ & $13.64 * *$ & $5236.80 * *$ \\
\hline P. vs. crosses & 1 & $393.56^{* *}$ & $328.22^{* *}$ & $19488.03 * *$ & $4094.76^{* *}$ & $227.37 * *$ & $7.51^{* * *}$ & $250.85^{* *}$ & $298005.42^{* *}$ \\
\hline GCA & 8 & 61.77 *** & $49.69^{* *}$ & $1648.08^{* * *}$ & $745.89 * *$ & $4.68^{* * *}$ & $0.22 * *$ & $11.68^{* * *}$ & $3183.95^{* *}$ \\
\hline$\sum \mathrm{g}^{2} \mathrm{i} / \Sigma \mathrm{S}^{2} \mathrm{ij}$ & & 0.596 & 0.558 & 0.517 & 0.69 & 0.14 & 0.16 & 0.25 & 0.08 \\
\hline
\end{tabular}

Similar results were reported by Alam $e t$ al. (2008), Barakat and Osman (2008), Sultan et al. (2011), Abdel-Moneam et al. (2009), Osman et al. (2012), Attia et al. (2013), Haddadi et al. (2014), AlHadad et al. (2015), Kanoosh (2018), Saeid et al. (2019) and Anees et al. (2019). Mean performance for days to $50 \%$ tasseling and silking, plant and ear height, length and diameter for ear, 100- kernel weight and grain yield/plant of the 9 parental inbred lines and their 36 crosses along with the check hybrids i.e. SC-136 and SC-10 are presented in Table (2). Results showed that; parent 3 was the earliest with 55.67 and 60.67 days to $50 \%$ tasseling and silking, respectively. On the other side, the cross P2 x P6 was the earliest for days to 50\% tasseling and silking with value 51.67 and 56.67 days, 
respectively, moreover, 14 and 13 crosses for days to $50 \%$ tasseling and silking, respectively, were significant and highly significant earlier than the earliest check SC-136, as well as, 20 and 16 crosses for days to $50 \%$ tasseling and silking, respectively, were significant and highly significant earlier than the earliest check SC-10. The tallest plant among the nine parents was noticed in parent 4 with $293.33 \mathrm{~cm}$, while the shortest inbred parent 2 with $214.00 \mathrm{~cm}$. On the other hand, the average of plant height for the 36 single crosses ranged from $233.00 \mathrm{~cm}$ for the cross P2 x P5 cm to $306.00 \mathrm{~cm}$ for the cross P4 x P6 with an average of 269.22. Moreover, 5 and 18 crosses were significant or highly significant and shortest than the check hybrids SC-136 and SC-10, respectively. For ear height the maximum value exhibited by parent 4 with $143.33 \mathrm{~cm}$ and minimum value $90.67 \mathrm{~cm}$ was shown for parent 3. On the other side, the cross $\mathrm{P} 4 \mathrm{x}$ P8 was the maximum with140.33 cm, while, the cross P2 x P5 the latest with $93.67 \mathrm{~cm}$, moreover, 7 and 16 crosses were significant and highly significant lower ear height than the check hybrids SC136 and SC-10, respectively. Finally, the cross P2 x P5 was the best for plant and ear height with value 233.00 and 93.67 $\mathrm{cm}$, respectively. For ear length showed that the parent 9 had the longest ear with $18.33 \mathrm{~cm}$, while the parent 7 had the shortest ear with $14.00 \mathrm{~cm}$. On the other side, the highest value was recorded for the cross P2 x P4 $(22.67 \mathrm{~cm})$. Moreover, some crosses did not differ significantly with the tow checks, except the cross P2 x P4 was negative significant than the ear length check hybrid SC-136. In the same (Table 2), the widest ear diameter was found in parent 2 with $5.07 \mathrm{~cm}$. On the contrary, the cross P2 x P6 was the highest value with $5.86 \mathrm{~cm}$, as well as 15 and 7 crosses for ear diameter were significant and highly significant widest than the check hybrids SC-136 and SC10, respectively. For 100-kernel weight parent 2 gave the highest value with $34.14 \mathrm{gm}$, On the other hand, results showed that ranged from $38.85 \mathrm{gm}$ for the P2 x P9 to $30.10 \mathrm{gm}$. for the P2 x P6, with an average with value $34.61 \mathrm{gm}$. Moreover, the five crosses (P1 x P5), (P1 x P9), (P2 x P4), (P2 x P9 and (P4 x P9) were positive and significant or highly significant heaviest than the check hybrid SC-136. Concerning to yield plant-1, the parent 1 showed the highest value with (204.56 g). On the other hand, the cross P1 x P8 was the best one in data with value $361.00 \mathrm{gm}$, moreover, 26 and 12 crosses were positive and significant or highly significant and over-yielded the two checks SC-136 and SC-10, respectively. These results indicated that all these promising crosses mentioned above had the most desirable SCA effects for earliness traits, plant height, ear height, ear length, ear diameter, 100kernel weight and grain yield/plant. Similar results were obtained by Wattoo et al. (2009), Zare et al. (2011), Ahmed (2013), Mosa et al. (2016), Bisen et al. (2017), Turkey et al. (2018) and Hussain and Hussen (2019). 
Table (2): Mean performance of the nine parental inbred lines and their 36 crosses of maize genotypes for all studied traits relative to check hybrids SC136 and SC10, during 2020 season.

\begin{tabular}{|c|c|c|c|c|c|c|c|c|}
\hline Parent & $\begin{array}{l}\text { Number of days } \\
\text { to } 50 \% \text { tasseling }\end{array}$ & $\begin{array}{l}\text { Number of days } \\
\text { to } 50 \% \text { silking }\end{array}$ & $\begin{array}{l}\text { Plant height } \\
(\mathrm{cm})\end{array}$ & $\begin{array}{l}\text { Ear height } \\
(\mathrm{cm})\end{array}$ & $\begin{array}{l}\text { Ear length } \\
(\mathrm{cm})\end{array}$ & $\begin{array}{c}\text { Ear diameter } \\
(\mathrm{cm})\end{array}$ & $\begin{array}{l}\text { 100- kernel } \\
\text { weight }(\mathrm{g})\end{array}$ & $\begin{array}{c}\text { Grain } \\
\text { yield/plant (g) }\end{array}$ \\
\hline p1 & 66.67 & 70.67 & 253.33 & 104.00 & 17.22 & 4.85 & 34.11 & 204.56 \\
\hline $\mathrm{p} 2$ & 61.67 & 66.67 & 214.00 & 94.00 & 16.72 & 5.07 & 34.14 & 172.33 \\
\hline p3 & 55.67 & 60.67 & 225.00 & 90.67 & 14.45 & 4.41 & 31.12 & 143.44 \\
\hline $\mathrm{p} 4$ & 70.33 & 74.33 & 293.33 & 143.33 & 16.56 & 4.69 & 32.27 & 157.67 \\
\hline p5 & 68.33 & 72.00 & 227.67 & 96.67 & 16.56 & 4.91 & 31.71 & 143.89 \\
\hline p6 & 62.00 & 66.67 & 230.33 & 85.33 & 17.22 & 4.63 & 27.74 & 154.89 \\
\hline p7 & 64.00 & 69.00 & 217.67 & 121.67 & 14.00 & 4.47 & 29.64 & 120.00 \\
\hline p8 & 69.33 & 73.00 & 238.00 & 100.33 & 18.33 & 4.40 & 29.14 & 133.65 \\
\hline p9 & 69.00 & 72.67 & 253.33 & 96.33 & 18.00 & 3.80 & 30.94 & 101.22 \\
\hline Mean & 65.22 & 69.52 & 239.19 & 103.59 & 16.56 & 4.58 & 31.20 & 147.96 \\
\hline \multicolumn{9}{|l|}{ Crosses } \\
\hline $\mathrm{P} 1 \mathrm{XP} 2$ & 58.00 & 62.67 & 290.33 & 128.00 & 20.33 & 5.36 & 35.24 & 252.11 \\
\hline P1 X P3 & 63.33 & 67.67 & 294.67 & 124.00 & 19.89 & 5.36 & 35.16 & 316.55 \\
\hline P1 X P4 & 63.67 & 68.00 & 296.67 & 128.67 & 17.22 & 4.85 & 34.38 & 235.50 \\
\hline PI X P5 & 61.67 & 66.00 & 283.33 & 119.67 & 20.44 & 5.36 & 38.69 & 326.67 \\
\hline P1 X P6 & 58.00 & 64.00 & 275.67 & 112.33 & 20.00 & 4.74 & 33.68 & 236.22 \\
\hline P1 X P7 & 58.67 & 63.67 & 275.33 & 125.33 & 18.56 & 4.80 & 33.81 & 243.89 \\
\hline P1 X P8 & 65.67 & 69.33 & 288.00 & 133.33 & 19.75 & 5.35 & 35.74 & 331.00 \\
\hline P1 X P9 & 66.67 & 71.67 & 278.33 & 126.67 & 22.22 & 4.87 & 38.00 & 305.00 \\
\hline P2 X P3 & 52.33 & 57.33 & 242.67 & 118.00 & 18.56 & 5.08 & 33.92 & 249.11 \\
\hline P2 X P4 & 64.67 & 69.00 & 286.67 & 129.00 & 22.67 & 5.35 & 38.28 & 325.11 \\
\hline P2 X P5 & 59.00 & 63.00 & 233.00 & 93.67 & 19.44 & 5.19 & 36.34 & 272.44 \\
\hline P2 X P6 & 51.67 & 56.67 & 244.33 & 121.00 & 19.89 & 5.86 & 34.80 & 271.11 \\
\hline P2 X P7 & 62.00 & 66.33 & 241.67 & 105.67 & 19.78 & 5.30 & 35.22 & 254.44 \\
\hline P2 X P8 & 63.00 & 67.33 & 260.33 & 107.67 & 19.45 & 5.36 & 33.12 & 272.11 \\
\hline P2 X P9 & 61.33 & 67.33 & 263.00 & 115.00 & 20.45 & 4.94 & 38.85 & 212.28 \\
\hline P3 X P4 & 55.00 & 60.00 & 284.33 & 129.00 & 17.89 & 5.46 & 32.59 & 330.56 \\
\hline P3 X P5 & 63.00 & 67.00 & 266.00 & 117.00 & 18.22 & 4.95 & 31.61 & 266.55 \\
\hline P3 X P6 & 54.67 & 60.00 & 276.00 & 113.67 & 19.33 & 5.30 & 32.55 & 264.29 \\
\hline P3 X P7 & 56.00 & 61.00 & 272.00 & 119.00 & 17.78 & 5.35 & 36.04 & 211.76 \\
\hline P3 X P8 & 63.33 & 67.67 & 264.00 & 114.33 & 19.11 & 5.07 & 32.59 & 224.67 \\
\hline P3 X P9 & 60.00 & 65.67 & 258.67 & 101.33 & 21.22 & 5.24 & 36.87 & 256.71 \\
\hline P4 X P5 & 66.67 & 69.67 & 250.00 & 120.00 & 20.33 & 5.12 & 35.63 & 321.67 \\
\hline P4 X P6 & 65.33 & 70.00 & 306.00 & 137.33 & 21.22 & 5.52 & 34.13 & 326.78 \\
\hline P4 X P7 & 61.67 & 66.67 & 284.67 & 134.33 & 18.78 & 4.91 & 33.11 & 300.89 \\
\hline P4 X P8 & 63.67 & 67.00 & 299.67 & 140.33 & 19.83 & 5.11 & 30.10 & 294.04 \\
\hline P4 X P9 & 64.33 & 68.33 & 299.33 & 135.00 & 21.55 & 5.24 & 37.62 & 295.89 \\
\hline P5 X P6 & 55.33 & 60.33 & 256.00 & 94.00 & 19.33 & 5.58 & 34.11 & 250.11 \\
\hline P5 X P7 & 56.00 & 61.33 & 237.67 & 104.67 & 18.67 & 5.41 & 35.17 & 213.44 \\
\hline P5 X P8 & 62.67 & 67.33 & 244.67 & 94.33 & 19.33 & 5.36 & 32.25 & 204.11 \\
\hline P5 X P9 & 62.33 & 67.33 & 256.33 & 94.00 & 20.00 & 5.42 & 35.03 & 276.56 \\
\hline P6 X P7 & 58.67 & 64.33 & 263.00 & 115.33 & 19.11 & 5.41 & 32.39 & 245.89 \\
\hline P6 X P8 & 59.67 & 64.67 & 259.00 & 110.67 & 21.44 & 4.98 & 34.53 & 238.22 \\
\hline P6 X P9 & 61.67 & 66.00 & 257.33 & 102.33 & 21.78 & 4.85 & 35.82 & 271.33 \\
\hline P7 X P8 & 64.00 & 68.33 & 269.33 & 124.33 & 19.45 & 4.85 & 34.12 & 247.44 \\
\hline P7 X P9 & 64.33 & 69.33 & 269.67 & 118.67 & 20.78 & 4.85 & 33.67 & 220.33 \\
\hline P8 X P9 & 66.33 & 70.33 & 264.33 & 117.33 & 19.22 & 4.41 & 30.78 & 190.33 \\
\hline Mean & 60.95 & 65.62 & 269.22 & 117.36 & 19.81 & 5.17 & 34.61 & 265.42 \\
\hline \multicolumn{9}{|l|}{ Checks } \\
\hline SC-10 & 66.67 & 70.00 & 257.00 & 114.33 & 21.33 & 5.01 & 33.96 & 208.22 \\
\hline SC-136 & 68.00 & 71.00 & 283.67 & 126.33 & 21.89 & 5.03 & 37.57 & 263.56 \\
\hline LSD 0.05 & 3.80 & 3.67 & 12.42 & 6.89 & 1.12 & 0.34 & 3.33 & 17.77 \\
\hline LSD 0.01 & 5.06 & 4.88 & 16.54 & 9.18 & 1.49 & 0.45 & 4.43 & 23.66 \\
\hline
\end{tabular}

\subsection{General combining ability effects}

General combining ability effects (gi) of 9 parental inbred lines for all studied traits are presented in Table (3), the obtained results cleared that the parent number 3 was significantly and desirable general combiner for number of days to $50 \%$ tasseling and number of days to $50 \%$ silking with values -3.55 and -3.30 , 
respectively, the parents 2,3 and 6 were found to be good general combiners for earliness traits and where they showed negative and highly significant GCA effects for these traits. With respect to plant and ear height, the parent number 5 with value -13.62 and -10.42 were significantly and the most superior general combiners for plant height and ear height, respectively.

Table (3): General combining ability effects of parental inbred lines for number of days to $50 \%$ tasseling and silking, plant and ear height, ear length, ear diameter 100-kernel weight and grain yield/plant, during 2020 season.

\begin{tabular}{|c|c|c|c|c|c|c|c|c|}
\hline Parent & $\begin{array}{l}\text { Number of days } \\
\text { to } 50 \% \text { tasseling }\end{array}$ & $\begin{array}{l}\text { Number of days } \\
\text { to } 50 \% \text { silking }\end{array}$ & $\begin{array}{l}\text { Plant height } \\
(\mathrm{cm})\end{array}$ & $\begin{array}{l}\text { Ear height } \\
(\mathrm{cm})\end{array}$ & $\begin{array}{l}\text { Ear length } \\
(\mathrm{cm})\end{array}$ & $\begin{array}{c}\text { Ear diameter } \\
(\mathrm{cm})\end{array}$ & $\begin{array}{l}\text { 100- kernel } \\
\text { weight }(\mathrm{g})\end{array}$ & $\begin{array}{c}\text { Grain } \\
\text { yield/plant (g) }\end{array}$ \\
\hline $\mathrm{P} 1$ & $0.99^{*}$ & $0.94 *$ & $14.26^{* *}$ & $5.45^{* *}$ & 0.12 & -0.01 & $1.24 * *$ & $21.53^{* *}$ \\
\hline P2 & $-2.07 * *$ & $-1.91 * *$ & $-12.92^{* * *}$ & $-3.64 * *$ & $0.22 *$ & $0.19 * *$ & $1.34 * *$ & 3.10 \\
\hline P3 & $-3.55^{* *}$ & $-3.30^{* *}$ & -2.17 & $-2.58 * *$ & $-0.97 * *$ & 0.01 & -0.52 & -1.11 \\
\hline $\mathrm{P} 4$ & $2.51^{* *}$ & $2.12^{* * *}$ & $23.80 * *$ & $17.66^{* *}$ & 0.09 & 0.04 & 0.10 & $29.68^{* * *}$ \\
\hline P5 & 0.48 & 0.18 & $-13.62^{* *}$ & $-10.49^{* * *}$ & $-0.24 * *$ & $0.15 * *$ & 0.27 & 0.00 \\
\hline P6 & $-2.64 * *$ & $-2.24 * *$ & $-3.10^{*}$ & $-6.25^{* *}$ & $0.45^{* * *}$ & $0.09 * *$ & $-1.07 * *$ & -0.50 \\
\hline P7 & $-0.79 *$ & -0.45 & $-7.59^{* * *}$ & $4.05^{* *}$ & $-0.97^{* *}$ & -0.06 & -0.59 & $-21.93 * *$ \\
\hline P8 & $2.63 * *$ & $2.18^{* * *}$ & -0.62 & -0.28 & $0.24 *$ & $-0.11 * *$ & $-1.61 * *$ & $-13.64 * *$ \\
\hline P9 & $2.45 * *$ & $2.48 * *$ & 1.96 & $-3.92 * *$ & $1.06^{* * *}$ & $-0.28 * *$ & $0.84 *$ & $-17.13 * *$ \\
\hline LSD (gi) 0.05 & 0.78 & 0.751 & 2.46 & 1.39 & 0.22 & 0.07 & 0.67 & 3.54 \\
\hline LSD (gi) 0.01 & 1.02 & 0.984 & 3.23 & 1.82 & 0.29 & 0.09 & 0.88 & 4.64 \\
\hline LSD (gi-gj) 0.05 & 1.171 & 1.126 & 3.695 & 2.079 & 0.329 & 0.100 & 1.005 & 5.313 \\
\hline LSD (gi-gj) 0.01 & 1.535 & 1.477 & 4.844 & 2.726 & 0.431 & 0.132 & 1.318 & 6.967 \\
\hline
\end{tabular}

*,** significant at 0.05 and 0.01 level of probability, respectively. S.E (gi) standard error for an GCA effect.

Moreover, the best inbred lines were P2, P5, P6 and P7, which had negative and significant or highly significant GCA effects for plant height, while, the best inbred lines were P2, P3, P5, P6 and P9 exhibited significant or highly significant negative GCA effects for ear height. These negative effects indicate the presence of favourable genes for both traits and that such inbred lines are good combiners for shortness and lower ear placement. Parents p2, p6, p8 and p9 showed significantly or highly significantly positive GCA effects for ear length, moreover, the highest desirable general combiners was the parent number 9 with value 1.06 . For ear diameter data in Table (4) cleared that the parents number 2, 5 and 6 were significantly the highest desirable general combiner and exhibited significant positive GCA effects, implying that this inbred lines may be posses favourable genes for prolificacy. In connection with 100-grain weight in Table (3) revealed that the parent number 2 with value 1.34 had the highest frequency of favorable alleles for 100-kernel weight. P1, P2 and P9 were found to be good general combiner for this trait. The best general combiners for grain yield/plant were $\mathrm{P} 1$ and $\mathrm{P} 4$ recoded 21.53 and 29.68, respectively, indicating that these parental inbred lines could be considered as good combiners for improving this trait. These parental inbred lines mentioned above could be the best combiners for all the studied traits, particularly parent 2 for no. of days to $50 \%$ tasseling, days to $50 \%$ silking, plant height, ear height, ear diameter and 
100-kernel weight. The parent 6 was good combiner for no. of days to $50 \%$ tasseling, days to $50 \%$ silking, plant height, ear height, ear length and ear diameter. The obtained results completely agreed with the points of view which were reported by Choukan
(1999), Alam et al. (2008), AbdelMoneam et al. (2009) and Haddadi et al. (2012). Amiruzzaman et al. (2013), Haddadi et al. (2014), Al-Hadad et al. (2015), Matin et al. (2016), Gamea et al. (2018), Anees et al. (2019) and Saeid et al. (2019).

Table (4): Specific combining ability effects of $36 \mathrm{~F} 1$ crosses for days to $50 \%$ tasseling and silking, plant height, ear height ear length, ear diameter 100-kernel weight and grain yield/plant, during 2020 season.

\begin{tabular}{|c|c|c|c|c|c|c|c|c|}
\hline Crosses & $\begin{array}{l}\text { Number of days } \\
\text { to } 50 \% \text { tasseling }\end{array}$ & $\begin{array}{l}\text { Number of days } \\
\text { to } 50 \% \text { silking }\end{array}$ & $\begin{array}{l}\text { Plant height } \\
(\mathrm{cm})\end{array}$ & $\begin{array}{l}\text { Ear height } \\
(\mathrm{cm})\end{array}$ & $\begin{array}{l}\text { Ear length } \\
(\mathrm{cm})\end{array}$ & $\begin{array}{c}\text { Ear diameter } \\
(\mathrm{cm})\end{array}$ & $\begin{array}{l}\text { 100- kernel } \\
\text { weight }(\mathrm{g})\end{array}$ & $\begin{array}{c}\text { Grain } \\
\text { yield/plant (g) }\end{array}$ \\
\hline P1 X P2 & $-2.73^{*}$ & $-2.76^{* *}$ & $25.78^{* *}$ & $11.59 * *$ & $0.84 * *$ & 0.13 & -1.27 & $-14.44 * *$ \\
\hline P1 X P3 & $4.09^{* * *}$ & $3.63^{* * *}$ & $19.36^{* * *}$ & $6.53 * *$ & $1.587 * *$ & $0.31 * *$ & 0.51 & $54.21^{* *}$ \\
\hline P1 X P4 & -1.64 & -1.46 & -4.61 & $-9.05^{* * *}$ & $-2.15^{* *}$ & $-0.23^{*}$ & -0.89 & $-57.63 * *$ \\
\hline PI X P5 & -1.61 & -1.52 & $19.48^{* * *}$ & $10.10^{* * *}$ & $1.41 * *$ & 0.17 & $3.25 * *$ & $63.21^{* *}$ \\
\hline P1 X P6 & $-2.16^{*}$ & -1.10 & 1.30 & -1.47 & 0.27 & $-0.38 * *$ & -0.41 & $-26.73 * *$ \\
\hline P1 X P7 & $-3.34 * *$ & $-3.22 * *$ & 5.45 & 1.22 & 0.25 & -0.18 & -0.77 & 2.36 \\
\hline P1 X P8 & 0.24 & -0.19 & $11.15^{* * *}$ & $13.56^{* * *}$ & 0.23 & $0.42 * *$ & $2.18 *$ & $81.19^{* *}$ \\
\hline P1 X P9 & 1.42 & 1.84 & -1.10 & $10.53^{* * *}$ & $1.89 * *$ & 0.11 & $1.99 *$ & $58.67 * *$ \\
\hline P2 X P3 & $-3.86 * *$ & $-3.86 * *$ & -5.46 & $9.62 * *$ & 0.15 & -0.17 & -0.84 & 5.19 \\
\hline P2 X P4 & $2.42^{*}$ & $2.39^{*}$ & $12.57 * *$ & 0.38 & $3.20^{* * *}$ & 0.08 & $2.91^{* * *}$ & $50.40^{* *}$ \\
\hline P2 X P5 & -1.22 & -1.67 & -3.67 & $-6.81 * *$ & 0.31 & $-0.20^{*}$ & 0.79 & $27.41^{* *}$ \\
\hline P2 X P6 & $-5.43 * *$ & $-5.58 * *$ & -2.86 & $16.29 * *$ & 0.06 & $0.53^{* *}$ & 0.60 & $26.59^{* *}$ \\
\hline P2 X P7 & $3.06^{* * *}$ & $2.30^{* * *}$ & -1.04 & $-9.35^{* *}$ & $1.37 * *$ & 0.13 & 0.53 & $31.34 * *$ \\
\hline P2 X P8 & 0.63 & 0.66 & $10.66^{* *}$ & -3.02 & -0.18 & $0.23^{*}$ & -0.53 & $40.72^{* * *}$ \\
\hline P2 X P9 & -0.86 & 0.36 & $10.75^{* * *}$ & $7.95 * *$ & 0.01 & -0.02 & $2.74 * *$ & $-15.62 * *$ \\
\hline P3 X P4 & $-5.76 * *$ & $-5.22 * *$ & -0.52 & -0.69 & $\begin{array}{l}-0.39 \\
\end{array}$ & $0.36^{* *}$ & -0.92 & $60.06^{* *}$ \\
\hline P3 X P5 & $4.27 * *$ & $3.72 * *$ & $18.57 * *$ & $15.47 * *$ & 0.28 & -0.26 & -2.07 & $25.73 * *$ \\
\hline P3 X P6 & -0.95 & -0.86 & $18.06^{* * *}$ & $7.89 * *$ & $0.69 *$ & 0.15 & 0.22 & $23.97 * *$ \\
\hline P3 X P7 & -1.46 & -1.64 & $18.54^{* *}$ & 2.92 & 0.56 & $0.36^{* *}$ & $3.22 * *$ & -7.13 \\
\hline P3 X P8 & $-3.28 * *$ & $-3.70 * *$ & $13.27 * *$ & $8.35 * *$ & 0.34 & 0.13 & $-2.31^{*}$ & $36.08 * *$ \\
\hline P3 X P9 & $-2.43^{* * *}$ & $-2.67^{*}$ & $10.36^{* *}$ & $6.65 * *$ & $1.24 * *$ & $0.43 * *$ & $2.75^{* * *}$ & $41.41^{* *}$ \\
\hline P4 X P5 & 1.87 & 0.96 & $-23.40^{* *}$ & -1.78 & $1.33^{* * *}$ & -0.12 & 1.33 & $50.05^{* *}$ \\
\hline P4 X P6 & $3.66^{* * *}$ & $3.72 * *$ & $22.09 * *$ & $11.32^{* * *}$ & $1.52 * *$ & $0.34 * *$ & 1.17 & $55.68 * *$ \\
\hline P4 X P7 & -1.86 & -1.40 & 5.24 & -1.99 & 0.50 & -0.12 & -0.33 & $51.21^{* * *}$ \\
\hline P4 X P8 & $-3.28 * *$ & $-3.70 * *$ & $13.27 * *$ & $8.35 * *$ & 0.34 & 0.13 & $-2.31 *$ & $36.08 * *$ \\
\hline P4 X P9 & $-2.43 * *$ & $-2.67^{*}$ & $10.36^{* * *}$ & $6.65 * *$ & $1.24 * *$ & $0.43 * *$ & $2.75^{* * *}$ & $41.41^{* * *}$ \\
\hline P5 X P6 & $-4.31 * *$ & $-4.01 * *$ & $9.51 *$ & -3.87 & -0.03 & $0.29 * *$ & 0.98 & 8.69 \\
\hline P5 X P7 & $-5.49 * *$ & $-4.79 * *$ & -4.34 & -3.50 & $0.73^{*}$ & $0.27 * *$ & 1.56 & -6.56 \\
\hline P5 X P8 & $-2.25 *$ & -1.43 & -4.31 & $-9.50 * *$ & 0.18 & $0.27 * *$ & -0.33 & $-24.18 * *$ \\
\hline P5 X P9 & $-2.40 *$ & -1.73 & 4.78 & $-6.20 * *$ & 0.03 & $0.50 * *$ & -0.01 & $51.75^{* *}$ \\
\hline P6 X P7 & 0.30 & 0.63 & $10.48^{* *}$ & 2.92 & 0.47 & $0.33^{* *} *$ & 0.12 & $26.39^{* *}$ \\
\hline P6 X P8 & -2.13 & -1.67 & -0.49 & 2.59 & $1.59 * *$ & -0.05 & $3.29 * *$ & $10.44 *$ \\
\hline P6 X P9 & 0.06 & -0.64 & -4.73 & -2.11 & $1.11^{* * *}$ & -0.01 & $2.12 *$ & $47.04^{* * *}$ \\
\hline P7 X P8 & 0.36 & 0.21 & $14.33^{* *}$ & $5.95 * *$ & $1.02 * *$ & -0.02 & $2.40 *$ & $41.08^{* *}$ \\
\hline P7 X P9 & 0.87 & 0.90 & $12.09^{* * *}$ & 3.92 & $1.53^{* * *}$ & 0.15 & -0.51 & $17.46^{* *}$ \\
\hline P8 X P9 & -0.55 & -0.73 & -0.22 & $6.92 * *$ & $-1.24 * *$ & $-0.25^{*}$ & $-2.38^{*}$ & $-20.83 * *$ \\
\hline C.D (Sij) 0.05 & 2.22 & 2.14 & 7.01 & 3.95 & 0.62 & 0.19 & 1.91 & 10.08 \\
\hline $\begin{array}{l}\text { C.D (Sij) } 0.01 \\
\end{array}$ & 2.91 & 2.80 & 9.19 & 5.17 & 0.82 & 0.25 & 2.50 & 13.22 \\
\hline
\end{tabular}

\subsection{Specific combining ability effects}

Estimates of specific combining ability effects (Sij) of 36 crosses for all studied traits in Table (4), showed that 14 and 11 crosses were negative and significant or highly significant desirable SCA effects for number of days to $50 \%$ tasseling and silking, respectively. The earliest crosses were $\mathrm{P} 3 \times \mathrm{P} 4$ and $\mathrm{P} 2 \times \mathrm{P} 6$ had highly 
significant and the highest negative SCA effects for these traits, indicating that these crosses are the best combinations for improving earliness traits. For plant height, one cross (P4 x P5) possessed significant negative SCA effects, indicating that this cross is the best combinations for improving shortness stature trait. Respecting ear height, five crosses P1 x P4, P2 x P5, P2 x P7, P5 x $\mathrm{P} 8$ and $\mathrm{P} 5 \mathrm{x}$ P9 had significant or highly significant negative SCA effects, the most superior specific combination toward low ear height was the cross P5 $x$ P8 with value $-9.50^{* *}$. These crosses mentioned above could be considered as the best combinations for all studied traits, specially the combinations $\mathrm{P} 3 \mathrm{x}$ P9, P4 x P9, P2 x P6, Also, results of Table (4), revealed that there were 16 , 14, 11 and 25 crosses possessed positive and significant or highly significant SCA effects for ear length, ear diameter, 100kernel weight and grain yield/plant, respectively. P3 x P4 and P5 x P9 had the most favourable SCA effects for most of the studied traits. Thus, the interaction of crosses should be evaluated with locations to identify the most single cross hybrids for increasing productivity in white maize. These results are in confidence with those of Uddin et al. (2006), Alam et al. (2008), Barakat and Osman (2008), Abdel-Moneam et al. (2009), Ofori et al. (2015), Matin et al. (2016), Wani et al. (2017), Gamea et al.
(2018), Hassan et al. (2019) and Raihan et al. (2019).

\subsection{Superiority percentages}

Superiority percentages in maize days to $50 \%$ tasseling and silking, plant height and ear height for the 36 new single crosses relative to two checks SC-136 and SC-10 are presented in Table (5). For days to $50 \%$ tasseling, out 36 crosses 28 and 32 crosses exhibited significant and negative standard heterotic values relative to $\mathrm{SC}-136$ and $\mathrm{SC} 10$, respectively. Also, 24 and 29 crosses expressed significant and negative standard heterotic values relative to SC136 and SC-10, respectively, moreover, the single cross P2 x P6 expressed the most desirable heterotic effect for days to $50 \%$ tasseling and silking relative to both checks. Regarding plant height, 6 crosses viz. $\mathrm{P} 2 \times \mathrm{P} 3, \mathrm{P} 2 \times \mathrm{P} 5, \mathrm{P} 2 \times \mathrm{P} 6, \mathrm{P} 2 \times \mathrm{P} 7$, $\mathrm{P} 5 \times \mathrm{P} 7$, and $\mathrm{P} 5 \times \mathrm{P} 8$ exhibited significant negative heterosis to SC-10. However, the single cross $\mathrm{P} 2 \times \mathrm{p} 5$ with value $-17.86 * *$ exhibited the best heterotic values to SC-10. For ear height, 8 and 16 crosses exhibited significant negative heterosis to SC-136 and SC-10, respectively, the highest negative and significant or highly significant heterosis for low ear height was recorded by the cross P2 $\times$ P5 with value $-18.08 * *$ and $25.86 * *$ relative to both checks SC-136 and SC-10, respectively. 
Table (5): Superiority percentages of the 36 maize single crosses relative to SC-136 and SC-10 for days to $50 \%$ tasseling, days to $50 \%$ silking, plant height and ear height, during 2020 season.

\begin{tabular}{|c|c|c|c|c|c|c|c|c|}
\hline \multirow{2}{*}{ Crosses } & \multicolumn{2}{|c|}{ Number of days to $50 \%$ tasseling } & \multicolumn{2}{|c|}{ Number of days to $50 \%$ silking } & \multicolumn{2}{|c|}{ Plant height $(\mathrm{cm})$} & \multicolumn{2}{|c|}{ Ear height $(\mathrm{cm})$} \\
\hline & SC-136 & SC-10 & SC-136 & SC-10 & SC-136 & SC-10 & SC-136 & SC-10 \\
\hline P1 X P2 & $-13.00 * *$ & $-14.71 * *$ & $-10.48 * *$ & $-11.74 * *$ & 12.97 *** & 2.35 & $11.95 * *$ & 1.32 \\
\hline P1 X P3 & $-5.00 * *$ & $-6.86^{* *}$ & -3.33 & $-4.70 *$ & $14.66^{* * *}$ & 3.88 & $8.46^{*}$ & -1.85 \\
\hline P1 X P4 & $-4.50 * *$ & $-6.37 * *$ & -2.86 & $-4.23 *$ & $15.44 * *$ & 4.58 & $12.54 * *$ & 1.85 \\
\hline PI X P5 & $-7.50 * *$ & $-9.31 * *$ & $-5.71 * *$ & $-7.04 * *$ & 10.25 & -0.12 & 4.67 & -5.28 \\
\hline P1 X P6 & $-13.00 * *$ & $-14.71 * *$ & $-8.57 * *$ & $-9.86 * *$ & 7.26 & -2.82 & -1.75 & $-11.08^{* * *}$ \\
\hline P1 X P7 & $-12.00 * *$ & $-13.73 * *$ & $-9.05 * *$ & $-10.33 * *$ & 7.13 & -2.94 & $9.62 * *$ & -0.79 \\
\hline P1 X P8 & -1.50 & -3.43 & -0.95 & -2.35 & 12.06 & 1.53 & $16.62 * *$ & 5.54 \\
\hline P1 X P9 & 0.00 & -1.96 & 2.38 & 0.94 & 8.30 & -1.88 & 10.79 ** & 0.26 \\
\hline P2 X P3 & $-21.50 * *$ & $-23.04 * *$ & $-18.10 * *$ & $-19.25 * *$ & -5.58 & $-14.45 * *$ & 3.21 & -6.60 \\
\hline P2 X P4 & -3.00 & $-4.90 *$ & -1.43 & -2.82 & 11.54 & 1.06 & $12.83^{* *}$ & 2.11 \\
\hline P2 X P5 & $-11.50 * *$ & $-13.24 * *$ & $-10.00 * *$ & $-11.27 * *$ & -9.34 & $-17.86 * *$ & $-18.08^{* * *}$ & $-25.86^{* *}$ \\
\hline P2 X P6 & $-22.50 * *$ & $-24.02 * *$ & $-19.05^{* *}$ & $-20.19 * *$ & -4.93 & $-13.87 * *$ & 5.83 & -4.22 \\
\hline P2 X P7 & $-7.00 * *$ & $-8.82^{* *}$ & $-5.24 * *$ & $-6.57 * *$ & -5.97 & $-14.81 * *$ & $-7.58^{*}$ & $-16.36^{* *}$ \\
\hline P2 X P8 & $-5.50^{* *}$ & $-7.35 * *$ & $-3.81^{*}$ & $-5.16^{* *}$ & 1.30 & -8.23 & -5.83 & $-14.78^{* *}$ \\
\hline P2 X P9 & $-8.00 * *$ & $-9.80^{* *}$ & $-3.81^{*}$ & $-5.16^{* *}$ & 2.34 & -7.29 & 0.58 & $-8.97 * *$ \\
\hline P3 X P4 & $-17.50 * *$ & $-19.12 * *$ & $-14.29 * *$ & $-15.49 * *$ & 10.64 & 0.24 & $12.83^{* *}$ & 2.11 \\
\hline P3 X P5 & $-5.50 * *$ & $-7.35^{* *}$ & $-4.29 *$ & $-5.63 * *$ & 3.50 & -6.23 & 2.33 & $-7.39 *$ \\
\hline P3 X P6 & $-18.00 * *$ & $-19.61 * *$ & $-14.29 * *$ & $-15.49 * *$ & 7.39 & -2.70 & -0.58 & $-10.03^{* * *}$ \\
\hline P3 X P7 & $-16.00 * *$ & $-17.65 * *$ & $-12.86 * *$ & $-14.09 * *$ & 5.84 & -4.11 & 4.08 & -5.81 \\
\hline P3 X P8 & $-5.00 *$ & $-6.86^{* *}$ & -3.33 & $-4.70^{*}$ & 2.72 & -6.93 & 0.00 & $-9.50 * *$ \\
\hline P3 X P9 & $-10.00 * *$ & $-11.77 * *$ & $-6.19 * *$ & $-7.51 * *$ & 0.65 & -8.81 & $-11.37 * *$ & $-19.79 * *$ \\
\hline P4 X P5 & 0.00 & -1.96 & -0.48 & -1.88 & -2.72 & -11.87 & 4.96 & -5.01 \\
\hline P4 X P6 & -2.00 & $-3.92 *$ & 0.00 & -1.41 & $19.07 * *$ & 7.87 & $20.12^{* * *}$ & 8.71 \\
\hline P4 X P7 & $-7.50 * *$ & $-9.31 * *$ & $-4.76^{*}$ & $-6.10^{* * *}$ & 10.77 & 0.35 & $17.49^{* *}$ & 6.33 \\
\hline P4 X P8 & $-4.50 *$ & $-6.37 * *$ & $-4.29 *$ & $-5.63^{* * *}$ & $16.60^{* * *}$ & 5.64 & $22.74 * *$ & $11.08^{* * *}$ \\
\hline P4 X P9 & -3.50 & $-5.39 * *$ & -2.38 & $-3.76^{*}$ & $16.47 * *$ & 5.52 & $18.08^{* *}$ & 6.86 \\
\hline P5 X P6 & $-17.00 * *$ & $-18.63^{* * *}$ & $-13.81 * *$ & $-15.02 * *$ & -0.39 & -9.75 & $-17.78 * *$ & $-25.59^{* *}$ \\
\hline P5 X P7 & $-16.00 * *$ & $-17.65^{* *}$ & $-12.38 * *$ & $-13.62 * *$ & -7.52 & $-16.22 * *$ & $-8.46^{*}$ & $-17.15^{* *}$ \\
\hline P5 X P8 & $-6.00 * *$ & $-7.84 * *$ & $-3.81^{*}$ & $-5.16^{* *}$ & -4.80 & $-13.75^{*} *$ & $-17.49 * *$ & $-25.33^{* *}$ \\
\hline P5 X P9 & $-6.50 * *$ & $-8.33^{* * *}$ & $-3.81^{*}$ & $-5.16^{* *}$ & -0.26 & -9.64 & $-17.78^{* * *}$ & $-25.59 * *$ \\
\hline P6 X P7 & $-12.00 * *$ & $-13.73 * *$ & $-8.10 * *$ & $-9.39 * *$ & 2.34 & -7.29 & 0.88 & $-8.71 *$ \\
\hline P6 X P8 & $-10.50 * *$ & $-12.26^{* *}$ & $-7.62 * *$ & $-8.92 * *$ & 0.78 & -8.70 & -3.21 & $-12.40^{* * *}$ \\
\hline P6 X P9 & $-7.50 * *$ & $-9.31 * *$ & $-5.71 * *$ & $-7.04 * *$ & 0.13 & -9.28 & $-10.50^{* * *}$ & $-19.00^{* *}$ \\
\hline P7 X P8 & $-4.00 *$ & $-5.88 * *$ & -2.38 & $-3.76^{*}$ & 4.80 & -5.05 & $8.75^{*}$ & -1.58 \\
\hline P7 X P9 & -3.50 & $-5.39 * *$ & -0.95 & -2.35 & 4.93 & -4.94 & 3.79 & -6.07 \\
\hline P8 X P9 & -0.50 & -2.45 & 0.48 & -0.94 & 2.85 & -6.82 & 2.62 & $-7.12 *$ \\
\hline LSD 0.05 & \multicolumn{2}{|c|}{3.801} & \multicolumn{2}{|c|}{3.666} & \multicolumn{2}{|c|}{12.42} & \multicolumn{2}{|c|}{6.89} \\
\hline LSD 0.01 & \multicolumn{2}{|c|}{5.061} & \multicolumn{2}{|l|}{4.882} & \multicolumn{2}{|c|}{16.54} & \multicolumn{2}{|c|}{9.18} \\
\hline
\end{tabular}

Standard heterosis effects for ear length, ear diameter, 100-kernel weight and grain yield/ plant relative to SC-136 and SC-10 presented in Table (6). For ear length, all crosses attained negative and significant or highly significant heterotic effect relative to tow checks, except three crosses i.e. P1 x P9, P2 x p4 and P6 x p9 manifested highly positive and significant heterosis relative to relative $\mathrm{SC}-136$ recoded $4.17 * *, 6.25 * *$ and $2.08 * *$ heterotic effects and two crosses i.e. P1 $\mathrm{x}$ $\mathrm{P} 9$ and $\mathrm{P} 2 \mathrm{x}$ p4 recorded $1.52 * *$ and $3.55^{* *}$ to relative $\mathrm{SC}-10$. These results revealed that these crosses were longer than the two check hybrids in ear length and could be used in breeding program for ear length in maize. Out of 36 hybrids 23 and 24 manifested highly positive and significant heterosis for ear diameter relative to SC-136 and SC-10, respectively. Moreover, the single cross P2 x P6 expressed the most desirable heterotic effect for this trait. Regarding 100-kernel weight, only one cross (P2 x P9) $(3.42 \%)$ showed merely positive and significant heterosis relative to check SC136, while, the respective heterotic values for the check SC-136, 15 out of 36 crosses manifested highly positive and significant heterosis for this trait, relative to this check, the single cross $\mathrm{P} 2 \times \mathrm{p} 5$ 
exhibited the best heterotic values to same check. For grain yield/plant, 25 and 7 crosses exhibited positive and significant heterotic relative to SC-136 and SC-10, respectively. However, the cross combination $\mathrm{P} 1 \times \mathrm{P} 8$ gave the most desirable heterotic effects relative to tow checks. Similar results were reported by Mosa et al. (2016), Sedhom et al. (2016), Bisen et al. (2017), Turkey et al. (2018) and Hussain and Hussen (2019).

\subsection{Genetic variance components}

Results of Table (7) show, estimates of additive genetic variance, dominance variances, genotypic variances, phenotypic variances, environmental variance, average degree of dominance, heritability in broad sence, heritability in narrow sence and expected genetic advance for the studied traits. The dominance variance was more than additive variance for ear length, ear diameter, 100-kernel weight and grain yield/plant. This indicated that these traits were under control of the dominance gene effect. Results also showed that the average degree of dominance $(\bar{a})$ was greater than one for all studied traits, indicating that these traits were under control of over dominance gene effect.

Table (6): Superiority percentages of the 36 maize single crosses relative to SC-136 and SC-10 for days to $50 \%$ tasseling, days to $50 \%$ silking, plant height and ear height, during 2020 season.

\begin{tabular}{|c|c|c|c|c|c|c|c|c|}
\hline \multirow{2}{*}{ Crosses } & \multicolumn{2}{|c|}{ Ear length $(\mathrm{cm})$} & \multicolumn{2}{|c|}{ Ear diameter $(\mathrm{cm})$} & \multicolumn{2}{|c|}{ 100- kernel weight (g) } & \multicolumn{2}{|c|}{ Grain yield/plant $(\mathrm{g})$} \\
\hline & SC-136 & SC-10 & SC-136 & SC-10 & SC-136 & SC-10 & SC-136 & SC-10 \\
\hline P1 X P2 & $-4.69^{* * *}$ & $-7.11 * *$ & $6.99 * *$ & 6.42 *** & $3.79^{*}$ & $-6.18^{* * *}$ & $21.08^{*}$ & -4.34 \\
\hline P1 X P3 & $-6.77 * *$ & $-9.14 * *$ & $6.99 * *$ & $6.42 * *$ & $3.54 *$ & $-6.41^{* * *}$ & $52.03 * *$ & $20.11^{*}$ \\
\hline P1 X P4 & $-19.27 * *$ & $-21.32 * *$ & $-3.06^{* * *}$ & $-3.58 * *$ & 1.24 & -8.49 ** & 13.10 & -10.64 \\
\hline PI X P5 & $-4.17 * *$ & $-6.61 * *$ & $6.99 * *$ & $6.42 * *$ & $13.94 * *$ & 2.99 & $56.88^{* * *}$ & $23.95^{* * *}$ \\
\hline P1 X P6 & $-6.25 * *$ & $-8.63 * *$ & $-5.26^{* * *}$ & $-5.76 * *$ & -0.80 & $-10.34 * *$ & 13.45 & -10.37 \\
\hline P1 X P7 & $-13.02 * *$ & $-15.23 * *$ & $-4.19^{* * *}$ & $-4.70 * *$ & -0.43 & $-10.00^{* * *}$ & 17.13 & -7.46 \\
\hline P1 X P8 & $-7.42 * *$ & $-9.78 * *$ & $6.86^{* * *}$ & $6.29 * *$ & $5.24 * *$ & $-4.87^{* * *}$ & $58.96^{* * *}$ & $25.59^{* *}$ \\
\hline P1 X P9 & $4.17 * *$ & $1.52 * *$ & $-2.80 * *$ & $-3.31 * *$ & $11.91^{\text {*** }}$ & 1.15 & $46.48^{* * *}$ & 15.72 \\
\hline P2 X P3 & $-13.02 * *$ & $-15.23 * *$ & $1.40 * *$ & $0.86^{* * *}$ & -0.12 & $-9.72^{* * *}$ & $19.64 *$ & -5.48 \\
\hline P2 X P4 & $6.25 * *$ & $3.55^{* *} *$ & $6.92 * *$ & $6.36^{* * *}$ & $12.72^{* * *}$ & 1.89 & $56.14 * *$ & $23.35^{* * *}$ \\
\hline P2 X P5 & $-8.86^{* *}$ & $-11.18 * *$ & $3.66^{* * *}$ & $3.11 * *$ & $7.01 * *$ & $-3.27 * *$ & $30.84 * *$ & 3.37 \\
\hline P2 X P6 & $-6.77 * *$ & $-9.14 * *$ & $16.98^{\text {*** }}$ & $16.36^{* * *}$ & 2.48 & $-7.36^{* * *}$ & $30.20^{* * *}$ & 2.87 \\
\hline P2 X P7 & $-7.30 * *$ & $-9.65 * *$ & $5.86^{* * *}$ & $5.30 * *$ & $3.71 *$ & $-6.26^{* * *}$ & $22.20^{*}$ & -3.46 \\
\hline P2 X P8 & $-8.84 * *$ & $-11.16 * *$ & $6.99 * *$ & $6.42 * *$ & -2.45 & $-11.83^{* * *}$ & $30.68 * *$ & 3.25 \\
\hline P2 X P9 & $-4.16^{* *}$ & $-6.59 * *$ & $-1.40 * *$ & $-1.92 * *$ & $14.41^{* * *}$ & $3.42 *$ & 1.95 & -19.46 \\
\hline P3 X P4 & $-16.14 * *$ & $-18.27 * *$ & $9.12 * *$ & $8.54 * *$ & $-4.02 *$ & $-13.25 * *$ & $58.75^{* * *}$ & $25.42 * *$ \\
\hline P3 X P5 & $-14.59 * *$ & $-16.77 * *$ & $-1.13^{* * *}$ & $-1.66 * *$ & $-6.90 * *$ & $-15.85 * *$ & $28.01 * *$ & 1.14 \\
\hline P3 X P6 & $-9.38^{* *}$ & $-11.68 * *$ & $5.86^{* * *}$ & $5.30^{* * *}$ & $-4.13 *$ & $-13.35^{* * *}$ & $26.92 * *$ & 0.28 \\
\hline P3 X P7 & $-16.67 * *$ & $-18.79 * *$ & $6.92 * *$ & $6.36^{* * *}$ & $6.15^{* * *}$ & $-4.06^{* *}$ & 1.70 & $-19.65^{* *}$ \\
\hline P3 X P8 & $-10.41 * *$ & $-12.68 * *$ & $1.33^{* * *}$ & $0.79 * *$ & $-4.02 *$ & $-13.25^{* * *}$ & 7.90 & -14.76 \\
\hline P3 X P9 & -0.53 & $-3.06 * *$ & $4.73 * *$ & $4.17 * *$ & 8.59 ** & -1.85 & $23.29 * *$ & -2.60 \\
\hline P4 X P5 & $-4.69 * *$ & $-7.11 * *$ & $2.26 * *$ & $1.72 * *$ & $4.94 * *$ & $-5.15^{* * *}$ & $54.48^{* * *}$ & $22.05^{*}$ \\
\hline P4 X P6 & -0.53 & $-3.06 * *$ & $10.25^{\text {*** }}$ & $9.67 * *$ & 0.51 & $-9.15^{* * *}$ & $56.94 * *$ & $23.99^{\text {*** }}$ \\
\hline P4 X P7 & $-11.98 * *$ & $-14.22 * *$ & $-1.93^{* * *}$ & $-2.45 * *$ & -2.48 & $-11.85^{* *}$ & $44.50 * *$ & 14.17 \\
\hline P4 X P8 & $-7.03 * *$ & $-9.40 * *$ & $2.06^{* * *}$ & $1.52 * *$ & $-11.35 * *$ & $-19.87 * *$ & $41.22 * *$ & 11.57 \\
\hline P4 X P9 & 1.03 & $-1.54 * *$ & $4.73 * *$ & $4.17 * *$ & $10.78^{\text {*** }}$ & 0.13 & $42.10^{* * *}$ & 12.27 \\
\hline P5 X P6 & $-9.38 * *$ & $-11.68 * *$ & $11.38^{\text {*** }}$ & $10.79^{* * *}$ & 0.45 & $-9.20 * *$ & $20.12 *$ & -5.10 \\
\hline P5 X P7 & $-12.50 * *$ & $-14.73 * *$ & $8.06 * *$ & $7.48^{* * *}$ & $3.58^{*}$ & $-6.37 * *$ & 2.51 & $-19.01 *$ \\
\hline P5 X P8 & $-9.38 * *$ & $-11.68 * *$ & $6.99 * *$ & $6.42 * *$ & $-5.02 * *$ & $-14.14 * *$ & -1.98 & $-22.56^{*}$ \\
\hline P5 X P9 & $-6.25 * *$ & $-8.63 * *$ & $8.26^{* * *}$ & $7.68^{* * *}$ & 3.17 & $-6.74 * *$ & $32.82 * *$ & 4.93 \\
\hline P6 X P7 & $-10.42 * *$ & $-12.70^{* * *}$ & $8.06^{* * *}$ & $7.48^{* * *}$ & $-4.61 * *$ & $-13.78^{* * *}$ & $18.09^{*}$ & -6.70 \\
\hline P6 X P8 & 0.52 & $-2.04 * *$ & $-0.53^{* * *}$ & $-1.06^{* * *}$ & 1.68 & $-8.09^{* * *}$ & 14.41 & -9.61 \\
\hline P6 X P9 & $2.08 * *$ & -0.52 & $-3.13^{* * *}$ & $-3.64 * *$ & $5.48^{* * *}$ & $-4.66^{* * *}$ & 30.31 ** & 2.95 \\
\hline P7 X P8 & $-8.84 * *$ & $-11.16 * *$ & $-3.06^{* * *}$ & $-3.58 * *$ & 0.49 & $-9.17 * *$ & $18.84^{*}$ & -6.11 \\
\hline P7 X P9 & $-2.61 * *$ & $-5.09 * *$ & $-3.06^{* * *}$ & $-3.58 * *$ & -0.85 & $-10.38 * *$ & 5.81 & -16.40 \\
\hline P8 X P9 & $-9.89 * *$ & $-12.18 * *$ & $-11.85^{* * *}$ & $-12.32 * *$ & $-9.36 * *$ & $-18.07 * *$ & -8.59 & $-27.78 * *$ \\
\hline LSD 0.05 & \multicolumn{2}{|c|}{1.120} & \multicolumn{2}{|c|}{0.337} & \multicolumn{2}{|c|}{3.327} & \multicolumn{2}{|c|}{17.766} \\
\hline LSD 0.01 & \multicolumn{2}{|c|}{1.491} & \multicolumn{2}{|c|}{0.449} & \multicolumn{2}{|c|}{4.430} & \multicolumn{2}{|c|}{23.658} \\
\hline
\end{tabular}

*, ** significant at 0.05 and 0.01 levels, respectively. 
Table (7): Estimates of genetic parameters, degree of dominance heritability, and expected genetic advance from selection for studied traits.

\begin{tabular}{|l|c|c|c|c|c|c|c|c|}
\hline Genetics & $\begin{array}{c}\text { Number of days } \\
\text { to 50\% tasseling }\end{array}$ & $\begin{array}{c}\text { Number of days } \\
\text { to 50\% silking }\end{array}$ & $\begin{array}{c}\text { Plant height } \\
(\mathrm{cm})\end{array}$ & $\begin{array}{c}\text { Ear height } \\
(\mathrm{cm})\end{array}$ & $\begin{array}{c}\text { Ear length } \\
(\mathrm{cm})\end{array}$ & $\begin{array}{c}\text { Ear diameter } \\
(\mathrm{cm})\end{array}$ & $\begin{array}{c}\text { 100-kernel } \\
\text { weight }(\mathrm{g})\end{array}$ & $\begin{array}{c}\text { Grain } \\
\text { yield/plant }(\mathrm{g})\end{array}$ \\
\hline$\sigma^{2} \mathrm{GCA}$ & 5.45 & 4.36 & 147.39 & 67.25 & 0.41 & 0.02 & 0.93 & 285.78 \\
\hline$\sigma^{2} \mathrm{SCA}$ & 9.14 & 7.82 & 278.92 & 97.54 & 2.91 & 0.12 & 3.73 & 3773.39 \\
\hline$\sigma^{2} \mathrm{~A}$ & 10.89 & 8.72 & 294.78 & 134.49 & 0.82 & 0.04 & 1.86 & 571.55 \\
\hline$\sigma^{2} \mathrm{D}$ & 9.14 & 7.82 & 278.92 & 97.54 & 2.91 & 0.12 & 3.73 & 3773.39 \\
\hline$\sigma^{2} \mathrm{e}$ & 1.86 & 1.72 & 26.81 & 6.19 & 0.16 & 0.01 & 1.45 & 40.41 \\
\hline$\sigma^{2} \mathrm{G}$ & 20.03 & 16.54 & 573.70 & 232.03 & 3.73 & 0.16 & 5.59 & 4344.94 \\
\hline$\sigma^{2} \mathrm{P}$ & 21.89 & 18.26 & 600.51 & 238.22 & 3.89 & 0.17 & 7.04 & 4385.36 \\
\hline$\overline{\mathrm{A}}$ & 1.30 & 1.34 & 1.38 & 1.20 & 2.66 & 2.50 & 2.00 & 3.63 \\
\hline $\mathrm{h}^{2} \mathrm{bs}$ & 91.52 & 90.59 & 95.50 & 97.40 & 96.00 & 91.60 & 79.50 & 99.10 \\
\hline $\mathrm{h}^{2} \mathrm{~ns}$ & 49.76 & 47.77 & 49.10 & 56.50 & 21.20 & 22.30 & 26.40 & 13.00 \\
\hline GA & 4.10 & 3.59 & 21.18 & 15.35 & 0.74 & 0.16 & 1.23 & 15.15 \\
\hline GA\% & 6.63 & 5.41 & 8.05 & 13.39 & 3.84 & 3.21 & 3.63 & 6.26 \\
\hline
\end{tabular}

These results agreed with the findings of Soliman et al. (2005), Hussein et al. (2015), Bawa et al. (2017) and Sadalla (2017). The present results in Table (7) show the very highest values $(>80 \%)$ of heritability in broad sense recorded for all studied traits, were $(91.52 \%)$ for number of days to $50 \%$ tasseling, (90.59\%) for number of days to $50 \%$ silking, (95.50\%) for plant height, ear height was (96.93\%), Ear diameter $(96.00 \%)$, ear diameter $(91.600 \%)$ and grain yield/plant per plant $(99.10 \%)$. Similarly, moderately high heritability values (60-79\%) were recorded for 100kernel weight $(79.50 \%)$, these results indicated that the variations were transmitted the progeny and indicated the potential for developing high yielding varieties through selection of desirable plants in succeeding generations. However, low heritability in narrow sence values was obtained for grain yield/plant $(13.00 \%)$. Thus, this trait is controlled by non-additive genes (dominance and epistasis), whereas medium heritability in narrow sense values were obtained for ear length (21.20\%), ear diameter (22.30\%), number of days to $50 \%$ tasseling (49.75), number of days to $50 \%$ silking (47.77), plant height (49.10) and 100- kernel weight $(26.40 \%)$, on the other hand, high heritability in narrow sense values were obtained for ear height (56.50). The excepted genetic advance from selection was very high (>20\%) only for plant height. Moderate values (10-20\%) were recorded for ear height and grain yield/plant. Some traits such as, days to $50 \%$ tasseling, days to $50 \%$ silking, ear length, ear diameter and 100-kernel weight showed low excepted genetic advance values $(<10 \%)$, whereas, the estimated of genetic advance as percent of mean (GA\%) in the present study was moderate GAM values (10-20\%) were recorded only for plant height. Also the traits i.e. days to $50 \%$ tasseling, days to $50 \%$ silking ear height, ear length, ear diameter, 100-kernel weight and grain yield/plant showed low GA\% values $(<10 \%)$. Obtained results agreed with those of Abd El-Sattar (2003), Rajesh et 
al. (2013) and Haochuan et al. (2014).

\section{Conclusion}

Our research concluded that: Parents P1 and P4 showed best GCA effects for grain yield/plant, while the parents P2, P5 and P6 appeared to be the best general combiners for most of the studied traits. Eight promising F1cross combinations $(\mathrm{P} 1 \times \mathrm{P} 5, \mathrm{P} 1 \times \mathrm{P} 8, \mathrm{P} 2 \times \mathrm{P} 4, \mathrm{P} 2 \times \mathrm{P} 5, \mathrm{P} 2 \times$ $\mathrm{P} 6, \mathrm{P} 3 \times \mathrm{P} 4, \mathrm{P} 4 \times \mathrm{P} 5$ and $\mathrm{P} 4 \times \mathrm{P} 6)$ were identified on the basis of per se performance, SCA and standard heterosis. In this study most of traits showed nonadditive gene effect, which played a great role in their inheritance with greater than one the average degree of dominance $(\bar{a})$, high value of heritability in broad sense and low values of heritability in narrow sense and low genetic advance values which preferred the hybridization and selection methods for improving these traits.

\section{References}

Abd El-Sattar, A. A. (2003), "Genetic parameters estimation from design-1 and S1lines in maize", Minufiya Journal of Agricultural Research, Vol. 28 No. 5, pp. 1387-1402.

Abdel-Moneam, M. A., Attia, A. N., ElEmery, M. I. and Fayed, E. A. (2009), "Combining ability and heterosis for some agronomic traits in crosses of maize" Pakistan Journal Of Biological Sciences, Vol. 12 No. 5, pp. 433-438.

Abrha, S. W. (2014), "Standard heterosis of maize (Zea mays L.) inbred lines for grain yield and yield related traits in central rift valley of Ethiopia", Journal of Biology, Agriculture and Healthcare, Vol.33 No. 4, pp. 31-37.

Ahmed, M. F. (2013), "Diallel analysis and biochemical makers for heterosis and combining ability under two sowing dates of maize inbred lines", Asian Journal of Crop Science, Vol. 1, pp. 81-94.

Ahmed, C., and Agrawal, V. (1982), "Heritability and genetic advance in triticale", Indian Journal of Agricultural Research, Vol. 16, pp.19-23.

Al- Hadad, A. S. (2015), "Heterosis and combining ability for yield and yield components in maize ( Zea mays L.)", Journal of Agricultural Chemistry and Biotechnology, Vol. 11 No. 6, pp. 447-460.

Alam, A. K. M., Ahmed, S., Begum, M., and Sultan, M. K. (2008), "Heterosis and combining ability of grain yield and its contributing characters in maize", Bangladesh Journal of Agricultural Research, Vol. 33 No. 3 pp. 375-379.

Al-Farari, A. K. (1999), Principles of genetics, $3^{\text {rd }}$ edition, Dar al-Kutub publications, Egypt.

Ali, A. A. (1999), Heterosis and gene action of maize (Zea mays L.), Ph.D. Thesis, Collage of Agriculture and Forestry, Mosul University, Iraq, (In 
Arabic).

Amiruzzaman, M., Islam, M. A., Hasan, L., Kadir, M. and Rohman, M. M. (2013), "Heterosis and combining ability in a diallel among elite inbred lines of maize (Zea mays L.)", Emirates Journal of Food and Agriculture, Vol. 25 No. 2 pp. $132-$ 137.

Anees, A., Al-Zubaidy, K., Al-Rawi, W. and AlDawody, S. (2019), "Study of genetic behavior for some productivity and morphology traits in half diallel cross of maize", Syrian Journal of Agricultural Research, Vol. 6 No. 1, pp. 134150.

Attia, A. N. E.,Badawi, M. A., Salama, A. M., Abdel-Moneam, M. A. and Leilah, A. A. A. (2013), "Combining ability and heterosis for maize grain yield and some agronomic characters", Journal of Plant Production, Vol .4 No. 4, pp. 551560.

Avinashe, H. A., Jaiwar, S. S., Girase, V. K., Rawool, S. A. and Khanorkar, S. M. (2013), "Assessment of heterosis and combining ability for biochemical components in crosses among high quality protein maize (Zea mays L.)", Journal of Soils and Crops, Vol. 23 No. 1, pp. 176-184.

Barakat, A. A. and Osman, M. M. A. (2008), "Gene action and combining ability estimates for some white promising maize inbred lines by top cross system", Journal of
Agricultural Science - Mansoura University, Vol. 33 No. 10, pp. 6995-7009.

Bawa, A., Addai, I. K. Abdulai, M. S. and Issahaku, A. H. (2017), "Diallel analysis and evaluation of parents and $\mathrm{F} 1$ progenies of maize ( $\mathrm{Zea}$ mays L.) for tolerance to drought and Striga hermonthica (Del.) Benth in the guinea savanna agroecological zone of Ghana", American Journal of Agricultural and Biological Sciences, Vol. 12 No.1, pp.44-54.

Bisen, P., Dadheech, A., Namrata, Nagar, O. and Meena, R. K. (2017), "Exploitation of Heterosis in Single Cross Hybrids of Quality Protein Maize (Zea maize L.) for Yield and Quality Traits", International Journal of Bio-Resource and Stress Management, Vol. 8 No.1, pp. 012019.

Choukan, R. (1999), "General and specific combining ability often maize inbred lines for different traits in diallel cross", Seed and Plant, Vol. 15 No.13, pp.280-295.

Comstock, R. E. and Robinson, H. F. (1952), "Estimation of average dominance of genes", In Heterosis, Gowen, J. W. (eds), Iowa State College Press, USA, pp.494-516.

Darwich, M. M. B., El-Ghonemy, M. A. M. and Balbaa, M. G. (2016), "Combining ability and superiority for yield and some related traits in half-diallel crosses nine new yellow 
maize inbred lines under two locations", Zagazig Journal of Agricultural Research, Vol. 43 No.16, pp. 2321-2335.

Dudly, J. W. and Moll, R. H. (1969), "Interpretation and use of estimates of heritability and genetic variances in plant breeding", Crop Sciences Journal, Vol. 9 No 3, pp. 257-261.

El-Badawy, M. E. M. (2013), "Heterosis and combining ability in maize using diallel crosses among seven new inbred lines", Asian Journal of Crop Sciences, Vol. 5 No.1, pp. 113.

El-Beially, I. E. M. A. (2003), "Genetic analysis of yield characters in yellow maize inbred lines", Zagazig Journal of Agricultural Research, Vol. 30 No. 3, pp. 677-689.

El-Beially, I. E., Mohamed, G. I. A. and Abd-El-Haleem, S. H. M. (2007), "Using line $\mathrm{x}$ tester method for estimation of combining ability effects in maize", Al-Azhar Journal of Agricultural Sciences, Vol. 3, pp. $1-12$.

Gamea, H., Darwich, M. and Aboyousef, H. A. (2018), "Combining ability for some inbred lines in half-diallel crosses of maize under two different locations conditions", Archives of Agriculture Sciences Journal, Vol. 1 No. 3, pp. 14-25.

Gomez, K. A. and Gomez, A.A. (1984), Statistical Procedures for
Agricultural Research, $2^{\text {nd }}$ Edition, A Wiley-intersclence Publication, John Wiley \& Sons, USA, pp. 357423.

Griffing, B. (1956), "Concept of general and specific combining ability in relation to diallel crossing system", Australian Journal of Biological Sciences, Vol. No. 9 pp. 463-493.

Haddadi, M. H., Esmaeilov, M., Choukan, R. and Rameeh, V. (2014), "Gene action and combing ability of some agronomic traits in corn using diallel analysis", Plant Breeding and Seed Science, Vol. 69, pp. 35-46.

Haddadi, M. H., Eesmaeilof, M., Choukan, R. and Rameeh, V. (2012), "Combining ability analysis of days to silking, plant height, yield components and kernel yield in maize breeding lines", African Journal of Agricultural Research, Vol. 7 No. 33, pp. 4685-4691.

Haochuan, L., Tang, J., Hn, Y., Yang J., and Liu, Z. (2014), "Analysis on combining ability and estimation of genetic parameters for chlorophyll content in maize", Journal of Plant Breeding and Crop Science, Vol. 6 No. 8, pp. 97-104.

Hassan, A. A., Jama, A. A., Mohamed, O. H. and Biswas, B. K. (2019), "Study on combining ability and heterosis in maize (zea mays L.) using partial diallel analysis", International Journal of Plant Breeding and Crop Science, 6 (2), 
pp. $520-526$.

Hussain, M. A. and Hussen, B. A. (2019), "Heritability and evaluation for some genetic parameters in single cross hybrids of maize (zea mays L.) traits", Journal of Duhok University, Vol. 22 No. 1, pp. 3847.

Hussein, M. A., Haji, S. E. and Ramadan, S. (2015), "Estimation of combining ability in maize lines using a diallel cross", Journal of Pure and Applied Science \& Technology, Vol. 27 No. 2, pp. 87-95.

Kanoosh, K. H. (2018), "Combining ability, gene action and heterosis in maize (zea mays L.)". Mesopotamia Journal of Agriculture, Vol. 46 No. 4, pp. 407-420.

Mather, K. and Jinks, J. L. (1982), Biometrical Genetics, $3^{\text {rd }}$ ed., Chapman and Hall, London.

Matin1, M. Q. I., Golam Rasul, Md., Aminul Islam, A. K. M., Khaleque Mian, M. A., Ivy, N. A. and Ahmed, J. U. (2016), "Combining ability and heterosis in maize (zea mays L.)", American Journal of Biosciences, Vol. 4 No.6, pp. 84-90.

Mostafa, M. (2018), "Estimation of combining ability in seven new yellow maize inbred lines for grain yield and some agronomic traits", Archives of Agriculture Sciences Journal, Vol. 1 No. 2, pp. 68-78.

Ofori, A. P., Ofori, K., Obeng-Antwi,
K., Tengan, K. M. L. and BaduApraku, B. (2015), "Combining ability and heterosis estimate of extra-early quality protein maize (QPM) single cross hybrids", Journal of Plant Breeding and Crop Science, Vol. 7 No. 4, pp. 87-93.

Raihan, H. Z., Sultana, And Hoque, M. (2019)," combining ability analysis for yield and yield contributing traits in maize (Zea mays L.)", Bangladesh Journal of Agricultural Research, Vol. 44 No. 2, pp. 253259.

Rajesh, V., Kumar, S. S., Reddy, V. N. and Sankar, A. S. (2013), "Studies on genetic variability, heritability and genetic advance estimates in newly developed maize senotypes (Zea mays L.)", International Journal of Applied Biology and Pharmaceutical Technology, Vol. 4 No. 4 pp. 242-244.

Ram, L., Singh, R., Singh, S. K. and Srivastava, R. P. (2015), "Heterosis and combining ability studies for quality protein in maize", Journal of Crop Breeding and Genetics, Vol. 1 No, 2, pp. 8- 25.

Reddy, V. R., Jabeen, F. and Sudarshan, M. R. (2015), "Heterosis studies in diallel crosses of maize for yield and yield attributing traits in maize ( $\mathrm{Zea}$ mays L.) over locations", International Journal of Agriculture Environment \& Biotechnology, Vol. 8 No.2, pp. 271-283.

Rohman, M. M., Omy, S. H., Begum, S., 
Rahman, M. A., Hossain, M. G., Hoque, M. M. and Amiruzzaman, M. (2019), "Genetic action and potence ratio of maize in an $8 \times 8$ diallel cross growing under saline condition", Journal of Plant Breeding and Crop Science, Vol. 11 No. 1, pp. 17-25.

Rojas, B. A. and Sprague, G. F. (1952), "A comparison of variance components in corn yield trials: III. General and specific combining ability and their interaction with locations and years", Agronomy Journal, Vol. 44 pp. 462-466.

Sadalla, H. A., Barznji, M. O. and Kakarash, S. A. (2017), "Full diallel crosses for estimation of genetic parameters in maize", The Iraqi Journal of Agricultural Sciences, Vol. 48, pp. 30-40.

Saeid, H. A. S., Majeed, A. H. and Shallal, A. S. (2019), "Estimation of Heterosis and Combining Ability For the yield Components in Single Crosses of Corn (Zea mays L.)", Syrian Journal of Agricultural Research, Vol. 6 No.4, pp. 210-220.

Sedhom, Y. S., Ali, M. M. A., Awaad, H. A. and Rabie, H. A. (2016), "Heterosis and factor analysis for some important traits in new maize hybrids", Zagazig Journal of Field Crop Science, Vol. 43 No. 3, pp. 711-728.

Singh, R. K. and Chaudhary, B. D. (1979), Biometrics Techniques in Genetics and Breeding, Kalyani
Publishers, Ludhiana, India, pp. 118.

Soliman, M. S. M., Nofal, F. A. E. and El-Azeem, M. E. M. A. (2005), "Combining ability for yield and other attributes in diallel cross of some yellow maize inbred lines", Minufia Journal of Agricultural Research, Vol. 30, pp. 1767-1781.

Sprague, G. F. and Tatum, L. A. (1942) "General vs specific combining ability in single cross of corn", Agronomy Journal, Vol. 34 No. 10, pp. 923-932.

Steel, R. G. and Torrie, J. (1980), Principles and procedures of statistics, McGraw-Hill Book Company, New York, USA.

Sultan, M. S., EI-Hosary, A. A., Leilah, A. A., Abdel Moneam, M. A. and Hamouda, M. A. (2011), "Combining ability for some important traits in red maize using Griffing's method 2 and 4", Journal of Plant Production, Vol. 2 No.6, pp. 811-822.

Sundararajan, R. and Kumar, P. S. (2011), "Studies on heterosis in maize (Zea mays L.)", Plant Archives, Vol. 11, pp.55-57.

Turkey, S. A., Omnya, H., Sedhom, M. E. L., El-Badawy, M. and ELHosary, A. A. A. (2018), "Combining ability analysis using diallel crosses among seven inbred lines of corn under two sowing dates", Annals of Agricultural Sciences, Moshtohor, Vol. 56 No.2, 
pp. 293-304.

Uddin, M. S., Khatun, F., Ahmed, S., Ali, M. R. and Bagum, S. A. (2006), "Heterosis and combining ability in corn (Zea mays L.)", Bangladesh Journal of Botany, Vol. 35 No. 2, pp. 109-116.

Wani, M. A., Wani, S. A., Dar, Z. A., Lone, A. A., Abedi, I. and Gazal, A. (2017), "Combining ability analysis in early maturing maize inbred lines under temperate conditions", International Journal of Pure \& Applied Bioscience, Vol. 5 No. 2, pp. 456-466.

Wattoo, F. M., Saleem, M., Ahsan, M., Sajjad, M. and Ali, W. (2009), "Genetic analysis for yield potential and quality traits in maize (Zea mays L.)", American-Eurasian Journal of Agricultural \& Environmental Sciences, Vol. 6 pp. 723-729.
Zaid, I. U., Rahman, H., Khan, S., Khan, S. U., Ullah, G., Rehman, M., Ullah, R. and Ahmed, N. (2014), "Heterosis response of three-way maize hybrids for grain yield and yield components", Journal of Agricultural Sciences, Vol. 3 No.1, pp. 24-29.

Zare, M., choukan, R., Bihamta, M. R., Heravan, E. M. and Kamelmanesh, M. M. (2011), "Gene action for some agronomic traits in maize (Zea mays L.)", Crop Breeding Journal, Vol. 1 No. 2, pp. 133-141. 